\title{
Trimethylamine emissions in animal husbandry
}

\author{
J. Sintermann ${ }^{1}$, S. Schallhart ${ }^{2}$, M. Kajos ${ }^{2}$, M. Jocher ${ }^{1}$, A. Bracher ${ }^{3}$, A. Münger ${ }^{3}$, D. Johnson ${ }^{4}$, A. Neftel ${ }^{1}$, and \\ T. Ruuskanen ${ }^{2}$ \\ ${ }^{1}$ Agroscope ISS, Zurich, Switzerland \\ ${ }^{2}$ University of Helsinki, Helsinki, Finland \\ ${ }^{3}$ Agroscope ILS, Posieux, Switzerland \\ ${ }^{4}$ SA Pathology, Adelaide, Australia
}

Correspondence to: J. Sintermann (joerg.sintermann@agroscope.admin.ch) and A. Neftel

(albrecht.neftel@agroscope.admin.ch)

Received: 10 April 2014 - Published in Biogeosciences Discuss.: 6 May 2014

Revised: 31 July 2014 - Accepted: 19 August 2014 - Published: 19 September 2014

\begin{abstract}
Degradation of plant material by animals is an important transformation pathway in the nitrogen $(\mathrm{N}) \mathrm{cy}-$ cle. During the involved processes, volatile reduced alkaline nitrogen compounds, mainly ammonia $\left(\mathrm{NH}_{3}\right)$ and aliphatic amines such as trimethylamine (TMA), are formed. Today, animal husbandry is estimated to constitute a main source of aliphatic amines in the atmosphere with TMA being the main emitted compound. Here, we show how the interaction between faeces and urine in animal production systems provides the primary source for agricultural TMA emissions. Excreted urine contains large quantities of urea and TMA$\mathrm{N}$-oxide, which are transformed into $\mathrm{NH}_{3}$ and TMA, respectively, via enzymatic processes provided by microbes present in faeces. TMA emissions from areas polluted with urine-faeces mixtures are on average of the order of 10 to $50 \mathrm{nmol} \mathrm{m}^{-2} \mathrm{~s}^{-1}$. Released amines promote secondary aerosol particle formation in the agricultural emission plume. The atmospheric lifetime of TMA, which was estimated to be of the order of 30 to $1000 \mathrm{~s}$, is determined by the condensation onto aerosol particles.
\end{abstract}

\section{Introduction}

Atmospheric reduced nitrogen species, such as amines or ammonia $\left(\mathrm{NH}_{3}\right)$, are crucial for secondary aerosol particle formation as they constitute the alkaline counterparts to acidic vapours, such as sulfuric and nitric acid (FinlaysonPitts and Pitts, 2000; Seinfeld and Pandis, 2006). Recent publications have suggested that aliphatic amines exhibit a po- tential for aerosol particle formation orders of magnitude higher than that of $\mathrm{NH}_{3}$ (Murphy et al., 2007; Kurten et al., 2008; Barsanti et al., 2009; Loukonen et al., 2010; Almeida et al., 2013). The influence of anthropogenically induced secondary particle formation has a potentially high impact on earth's radiative forcing (Lohmann and Feichter, 2005; IPCC, 2013) and human health (Pope et al., 2002). There is a large knowledge gap for linking amine sources, their distribution, and secondary particle formation (Andreae, 2013; Kulmala et al., 2013). Additionally, measurements of ambient amine concentrations are scarce. However, among the volatile aliphatic amine species, trimethylamine (TMA) release from agriculture constitutes the most dominant source and, consequently, TMA has been found to be the dominant gas-phase aliphatic amine (compared to methylamine (MMA) and dimethylamine (DMA), for example) at agricultural sites with a molar ratio TMA : $\mathrm{NH}_{3}$ between 0.3 and $1 \%$ at animal housing and feedlots (Hutchinson et al., 1982; Schade and Crutzen, 1995; Kuhn et al., 2011) (see also Kuwata et al., 1983; Grönberg et al., 1992; Kallinger and Niessner, 1999; Rappert and Müller, 2005; Schade and Ngwabie, 2005; Filipy et al., 2006; Ngwabie et al., 2008; Blanes-Vidal et al., 2009; Feilberg et al., 2010; Ge et al., 2011; Trabue et al., 2011; Dawson et al., 2014). Based on this narrow range, Schade and Crutzen (1995) provided an estimate of the global aliphatic amine emissions by scaling with the more detailed assessed $\mathrm{NH}_{3}$ emissions. Subsequently, it has been shown that the TMA- $\mathrm{NH}_{3}$ analogy is not generally transferable to all agricultural emission stages, as stored cattle slurry is considerably TMA-depleted. The 
global agricultural amine supply has been refined accordingly (Kuhn et al., 2011). Since cattle rumen content contains a very high proportion of volatile TMA, Kuhn et al. (2011) discussed the hypothesis that ruminants may exhale high concentrations of TMA by rumination. However, no measurements under real conditions have so far supported this hypothesis. The relevance of amine emissions to aerosol particle formation (Almeida et al., 2013) motivates this study to gain more information on the formation mechanism and emission of agricultural TMA. The focus lies on TMA emission pathways in dairy systems, investigated by ambient trace gas concentration as well as laboratory dynamic chamber measurements. We further discuss the fate of the identified agricultural TMA emissions and their role in secondary aerosol particle formation.

\section{Material and methods}

\subsection{Concentration measurements at the dairy cattle barn}

Measurements were carried out in summer 2011 at a dairy cattle barn at the Federal Research Station in Posieux, Switzerland $\left(7.10653^{\circ}\right.$ E, $46.7692^{\circ} \mathrm{N} ; 640 \mathrm{~m}$ a.s.l.). The herd consisted of 60 dairy cows (average live weight $680 \mathrm{~kg}$, average annual milk production of $8500 \mathrm{~kg}$ per cow) milked twice a day: early in the morning and in the afternoon. Before and after milking, the cattle spent approximately 3 to $5 \mathrm{~h}$ in the barn complex in a farmyard (surrounded on three sides by the barn). During most of this time they had access to feeding stations providing them a concentrated ration of a cereal mix, offered in individual amounts based on standardised current milk production and maintenance requirements. They also had access to feed bunks to consume a limited daily amount of maize silage. The remainder of the day the herd was on pasture. The yard's concrete ground was cleaned with automatic scrapers, usually within $1 \mathrm{~h}$ after the cattle had left. Based on high-temperature chemical ionisation mass spectrometry (HT-CIMS), proton transfer reaction time-of-flight mass spectrometry (PTR-TOF-MS), and cavity ring-down spectroscopy (CRD) (see Sect. 2.3), diurnal patterns of ambient trace gas concentrations in the outdoor yard were measured at $3 \mathrm{~m}$ height over 3.5 days. In addition, short-period trials were pursued measuring close (within $10 \mathrm{~cm}$ ) to the mouth of ruminating cattle. Measured target trace gas species were $\mathrm{NH}_{3}$, TMA, acetone, and $\mathrm{CH}_{4}$.

\subsection{Emission measurements with dynamic chambers}

In order to quantify TMA and $\mathrm{NH}_{3}$ emissions in a controlled environment, a dynamic chamber (Pape et al., 2009) was placed over different excretion substrates (see below) inside a climate-controlled $\left(20^{\circ} \mathrm{C}\right.$, relative humidity of $\left.60 \%\right)$ well-ventilated room. Given steady state and no trace gas destruction or creation, such as chemical conversion inside the chamber, the substrate chamber flux $F_{\text {cham }}$ is derived by

$F_{\text {cham }}=\frac{Q}{A} \cdot \rho_{\mathrm{d}}\left(c_{\text {cham }}-c_{\text {amb }}\right)$,

where $Q$ is the purging air flow rate, $A$ denotes the area of investigated surface inside the chamber, $\rho_{\mathrm{d}}$ is the density of dry air, and $c_{\text {cham }}$ and $c_{\text {amb }}$ represent the trace gas mixing ratios inside and outside of the dynamic chamber, respectively (Pape et al., 2009).

The cylindrical chamber with walls of PFA (Perfluoroalkoxy alkane) film had an enclosed headspace volume of $41 \mathrm{~L}$ and was continuously flushed at $60 \mathrm{~L} \mathrm{~min}^{-1}$ of ambient air. It was setup on a base into which a circular plastic sample container $\left(A=0.049 \mathrm{~m}^{2}\right)$ was placed. $c_{\mathrm{amb}}$ and $c_{\text {cham }}$ were measured for $\mathrm{NH}_{3}$ and TMA by CRD, HT-CIMS, and impinger sampling combined with ion chromatography (IC) analysis.

On 9 February 2012, urine and faeces were collected upon excretion at the cattle barn in Posieux. Stored slurry from the slurry pit was also collected. The samples were sealed airtight, cooled, and brought to the laboratory within $6 \mathrm{~h}$. The substrates were subdivided and recombined to a $2: 1$ urine-faeces mixture immediately before the first measurement. For this, $1 \mathrm{~L}$ subsamples were prepared in the sample containers. Both sets, the subsamples and remaining fractions, were stored in separate climate rooms under similar conditions throughout the entire experiment period of about $160 \mathrm{~h}$. For measurements, each subsample was put inside the dynamic chamber for 30 to $60 \mathrm{~min}$. After some minutes it was stirred for $1 \mathrm{~min}$. Average fluxes were calculated subsequently to stirring considering chamber equilibration time (with respect to $\mathrm{NH}_{3}$ and TMA wall adsorption and desorption effects), which was determined to be less than $5 \mathrm{~min}$. $\mathrm{pH}$ values were monitored (pH-3310, WTW, Germany). The $\mathrm{pH}$ rod was cleaned using demineralised water following each measurement. To estimate maximum emission potentials of the volatile pools of $\mathrm{NH}_{3}$ and TMA, each substrate was additionally investigated at the beginning, during, and at the end of the whole measurement period by adding $\mathrm{NaOH}$ solution to $1 \mathrm{~L}$ aliquots from the parallel samples immediately before measurement until substrate $\mathrm{pH}$ exceeded 12 . This way, dissolved TMA and $\mathrm{NH}_{3}$ are supposed to be driven into the gas phase. Between all treatments the chamber lid was opened for a minimum of $10 \mathrm{~min}$ to let the chamber volume and surfaces equilibrate with the ambient concentration.

\subsection{Concentration determination}

\subsubsection{At the dairy cattle barn}

Concentrations of trace gas species were recorded online, with a combination of PTR-TOF-MS for volatile organic compounds (VOCs; including TMA) (Ionicon Analytik GmbH, Austria; Jordan et al., 2009; Graus et al., 2010), HT-CIMS (based on PTR-MS, Ionicon Analytik GmbH, 
Austria) for $\mathrm{NH}_{3}$ and TMA (Sintermann et al., 2011), and a CRD analyser for $\mathrm{CH}_{4}$ (Los Gatos Research, CA, USA). Flexible inlet lines were used in order to sample at different locations. PTR-TOF-MS and HT-CIMS subsampled from a common $24 \mathrm{~m} 1 / 2 \mathrm{in}$. OD PFA inlet line flushed at about $80 \mathrm{~L} \mathrm{~min}^{-1}$. The inlet line was heated above $150^{\circ} \mathrm{C}$ in order to achieve response times for $\mathrm{NH}_{3}$ and TMA of the order of seconds (Sintermann et al., 2011). The CRD sampled through a parallel $1 / 4$ in. OD PFA tube. For distinct TMA and $\mathrm{NH}_{3}$ calibration events with PTR-TOF-MS and HTCIMS, impingers (64712-U, Supelco, USA) sampled air in $15 \mathrm{~mL} \mathrm{H}_{2} \mathrm{SO}_{4}\left(0.1 \mathrm{~mol} \mathrm{~L}^{-1}\right)$ solution with an airflow rate of $0.6 \mathrm{~nL} \mathrm{~min}^{-1}$. The solution was analysed offline by IC as described by Kuhn et al. (2011). Applying two impingers in series resulted in TMA and $\mathrm{NH}_{3}$ breakthrough of less than $2 \%$, even at high concentration levels of approximately $800 \mathrm{ppb}$ $\mathrm{NH}_{3}$ and $10 \mathrm{ppb}$ TMA. The HT-CIMS instrument was operated with $E / N \approx 121 \mathrm{Td}$ at $180^{\circ} \mathrm{C}$. With this setup, TMA is detected primarily at $\mathrm{m} / z 58$ with an $E / N$-dependent fraction also occurring at $\mathrm{m} / z 59(10-35 \%)$, whereas acetone peaks at $m / z 59$ with a minor fraction at $m / z 58(15 \%)$. This potential for cross-interference has been included as a range of possible values in the HT-CIMS concentration calculation for TMA. PTR-TOF-MS and HT-CIMS were calibrated for TMA and $\mathrm{NH}_{3}$, respectively, by impingers sampling ambient air in parallel ( $n=8$ for $\mathrm{NH}_{3}, n=6$ for TMA). The HTCIMS zero offset was determined by zero air measurements, with air provided by an LN Industries (Geneva, Switzerland) permeation device. The PTR-TOF-MS calibration setup for selected VOCs (as in Taipale et al., 2008) and concentration calculation procedures are described in more detail in the Supplement.

\subsubsection{Dynamic chamber measurements}

The climate room $\mathrm{NH}_{3}$ amb concentration was continuously monitored using a CRD instrument (Picarro Inc., CA, USA) with a $15 \mathrm{~cm}$ long $1 / 4 \mathrm{in}$. OD PFA inlet, sampling with $0.5 \mathrm{~nL} \mathrm{~min}^{-1}$ close to the dynamic chamber inflow. Additionally, $\mathrm{NH}_{3}$ amb and $\mathrm{TMA}_{\mathrm{amb}}$ concentrations were periodically determined with impingers (as outlined in Sect. 2.3.1). These data revealed that TMA did not accumulate in the climate room, and hence $\mathrm{TMA}_{\mathrm{amb}}$ was set constant; this also corresponded to HT-CIMS observations before and after the dynamic chamber measurements. The chamber headspace concentrations, $\mathrm{TMA}_{\text {cham }}$ and $\mathrm{NH}_{3 \text { cham }}$, were continuously monitored at the centre of the volume by means of HT-CIMS (operated similarly as during the cattle barn concentration measurements) equipped with a $65 \mathrm{~cm}$ long $1 / 4 \mathrm{in}$. OD PFA inlet line, heated to $150{ }^{\circ} \mathrm{C}$ and flushed at $0.9 \mathrm{~nL} \mathrm{~min}^{-1}$. In addition, the impinger system described in Sect. 2.3.1 was operated in parallel to the HT-CIMS inside the dynamic chamber for some occasions. The CRD and HT-CIMS were calibrated for $\mathrm{NH}_{3}$ using gas from a standard bottle (50 ppm $\mathrm{NH}_{3}$ ) down-mixed by a mass flow controller with zero con-

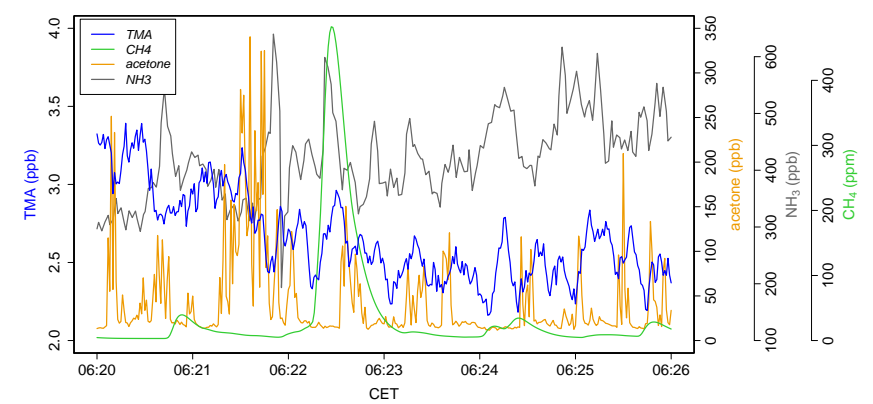

Figure 1. High-resolution time series of acetone, $\mathrm{NH}_{3}$, and TMA ( $8 \mathrm{~s}$ moving average) during measurements in front of the mouth of a ruminating cow at the outdoor yard on 28 July 2011; the average TMA : $\mathrm{NH}_{3}$ ratio for this period was $0.65 \%$.

centration bottled synthetic air. This zero air stream was guided through two large $(0.25 \mathrm{~L})$ impingers with $\mathrm{H}_{2} \mathrm{SO}_{4}$ solution $\left(0.01 \mathrm{~mol} \mathrm{~L}^{-1}\right)$ and demineralised water, setup in a temperature-regulated water bath in order to ensure gas relative humidity of $60 \%$ at $20^{\circ} \mathrm{C}$ - the same as in the climate room. For $\mathrm{NH}_{3}$ calibration, the $\mathrm{NH}_{3}$ gas was mixed into this air stream. The air stream was supplied to the CRD and HT-CIMS over a T-piece with an overflow. Overflow impinger sampling with IC analysis was applied to check the calibration gas concentration. These calibrations were performed over at least $2.5 \mathrm{~h}$ to ensure sufficient equilibration time with involved surfaces. TMA calibration factors for HT-CIMS were obtained by comparison with impinger samples that had been collected during parallel operation of HTCIMS and impingers inside the dynamic chamber. Applying two impingers in series resulted in less than $3 \%$ breakthrough even at mixing ratios of approximately $3 \mathrm{ppm} \mathrm{NH}_{3}$ and 80 ppb TMA.

\section{Results}

\subsection{Concentration measurements}

\subsubsection{Exhaling cow}

To test the hypothesis that ruminating animals exhaling TMA-enriched breath is the main TMA source, air was sampled close to the mouth of a ruminating cow. Figure 1 shows such a test with high time-resolution. Peaks in the acetone concentration time course mark the collection of air enriched by the animal's respiration (Elliott-Martin et al., 1997; Turner et al., 2012). $\mathrm{CH}_{4}$ is related to eructation and respiration. $\mathrm{NH}_{3}$ and TMA concentrations in the surrounding air were highly variable. They did not significantly correlate with the observed peaks in acetone and $\mathrm{CH}_{4}$. The mean TMA concentration was $2.7 \mathrm{ppb}$ with a maximum of $4.5 \mathrm{ppb}$ while the average TMA : $\mathrm{NH}_{3}$ ratio during the displayed period was $0.65 \%$ (see Sect. 3.1.2). 


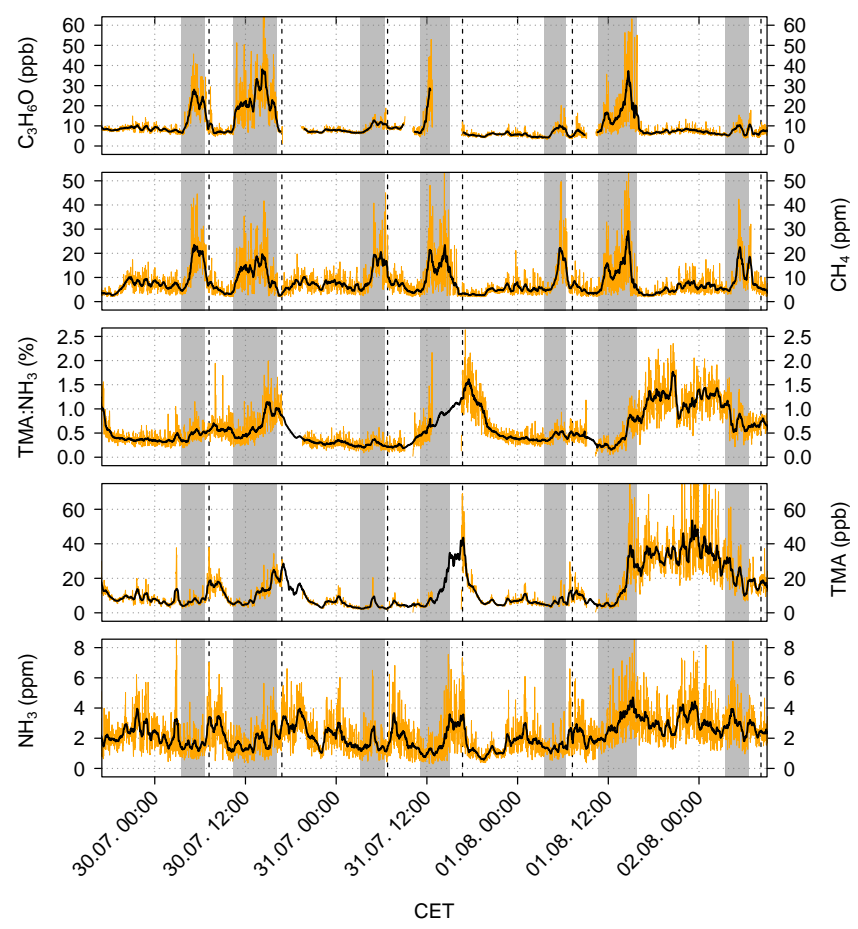

Figure 2. One-minute (orange) and $30 \mathrm{~min}$ (black) moving average trace gas concentrations measured in the outdoor yard; the presence of the animals is indicated with grey bars; ground scraping is represented by vertical dashed lines.

\subsubsection{Diurnal variations at the outdoor barn area}

Over a period of 3.5 days, trace gas concentrations were monitored in the farmyard (Fig. 2). The animals were usually away on pasture, but were gathered twice a day in the yard in the early morning and around noon (grey bars in Fig. 2). Typical concentration levels without the direct influence of animals were approximately $8 \mathrm{ppb}$ acetone, 3 to $7 \mathrm{ppm} \mathrm{CH}_{4}, 2 \mathrm{ppm} \mathrm{NH_{3 }}, 6 \mathrm{ppb} \mathrm{TMA}$, corresponding to $0.3 \% \mathrm{TMA}: \mathrm{NH}_{3}$. The animals' presence immediately correlated with strongly elevated acetone and $\mathrm{CH}_{4}$ concentrations (Figs. 2 and 3). In contrast, $\mathrm{NH}_{3}$ and TMA concentrations, as well as the ratio, began to increase subsequent to the cows' arrival, with a delay of around $2 \mathrm{~h}$. However, their maximum average levels of approximately $4 \mathrm{ppm} \mathrm{NH}_{3}$, $50 \mathrm{ppb}$ TMA, and $1.5 \%$ TMA : $\mathrm{NH}_{3}$ were reached when the cattle were gone and persisted as long as the barn's concrete floor was polluted with an excrement layer. The highest $1 \mathrm{~min}$ TMA values were approximately $120 \mathrm{ppb}$ and TMA : $\mathrm{NH}_{3}$ peaked at $2.6 \%$. The activation of the ground scraper and water cleaning of the ground (dashed line in Fig. 2) preceded declines in TMA and TMA : $\mathrm{NH}_{3}$ levels. Typically, the concentration peaks were more pronounced in the afternoon than in the morning. An interesting feature from Fig. 2 is the plateau of the TMA and $\mathrm{NH}_{3}$ concentrations as well as their ratio observed on the afternoon of 1 August onwards.
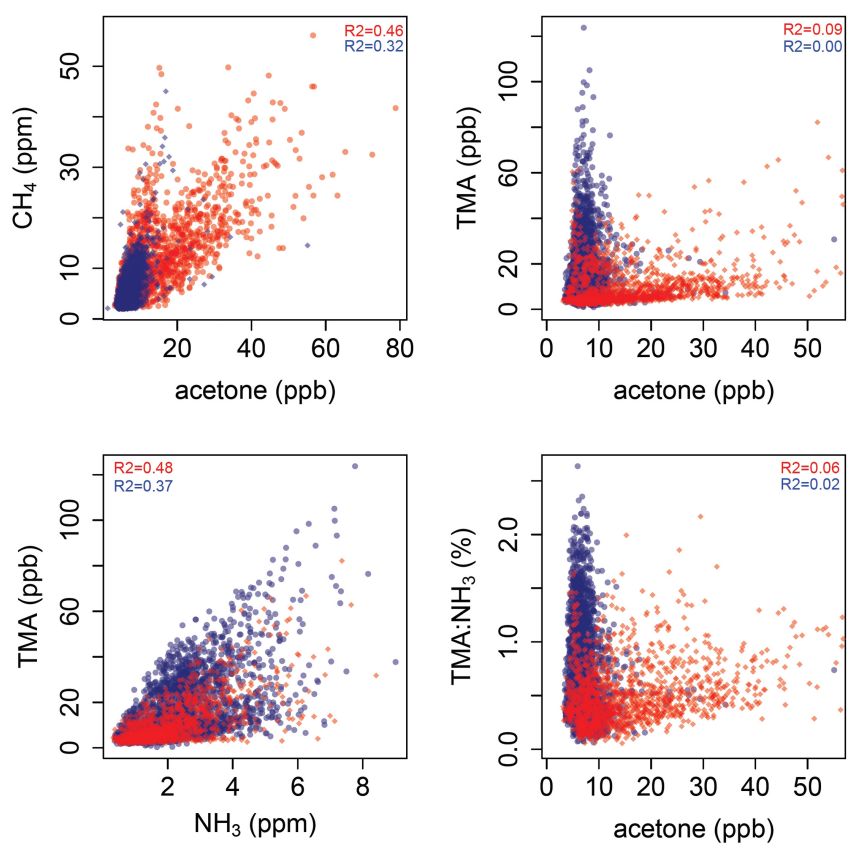

Figure 3. Mixing ratio correlation plots (1 min averages) for the period 29 July 17:00 to 2 August 9:00 (also shown in Fig. 2) of (a) $\mathrm{CH}_{4}$ vs. acetone, (b) TMA vs. acetone, (c) TMA vs. $\mathrm{NH}_{3}$, (d) TMA : $\mathrm{NH}_{3}$ vs. acetone; red circles are the measurements during presence of cows, blue diamonds are in absence of cows.

Under usual operation, the yard's ground is cleaned a short time after the cows leave the barn. This cleaning procedure did not take place that one afternoon and the excrement mixture remained on the ground until the next morning. During that entire episode, the elevated TMA concentration levels remained. Simultaneously measured wind speeds (at $1.5 \mathrm{~m}$ a.g.1.) in the farmyard were always below $1 \mathrm{~m} \mathrm{~s}^{-1}$ coming from variable directions. Ambient air temperature was lowest in the early morning at 13 to $15^{\circ} \mathrm{C}$, and peaked during daytime at 23 to $26^{\circ} \mathrm{C}$. We therefore assume that the observed air concentrations are not mainly caused by variations of atmospheric transport capacity, but that the measured concentrations primarily scale with emission rates.

Figure 3 summarises the findings of Fig. 2 with scatterplots subdivided into values reflecting periods with and without cattle. Figure 3 shows that high levels of acetone and $\mathrm{CH}_{4}$ correlate and are linked to direct emissions from the animals, whereas the occurrence of high $\mathrm{NH}_{3}$ and especially TMA concentrations is decoupled from direct animal emissions.

\subsection{Emission measurements}

Figure 4 summarises the dynamic chamber emission measurements for $\mathrm{NH}_{3}$ and TMA. $\mathrm{NH}_{3}$ emissions were dominated by volatilisation from the urine-faeces mixture. After about $45 \mathrm{~h}$, emissions began to decrease again. Direct faecal and urinary emissions played a minor role. $\mathrm{pH}$ values tended 

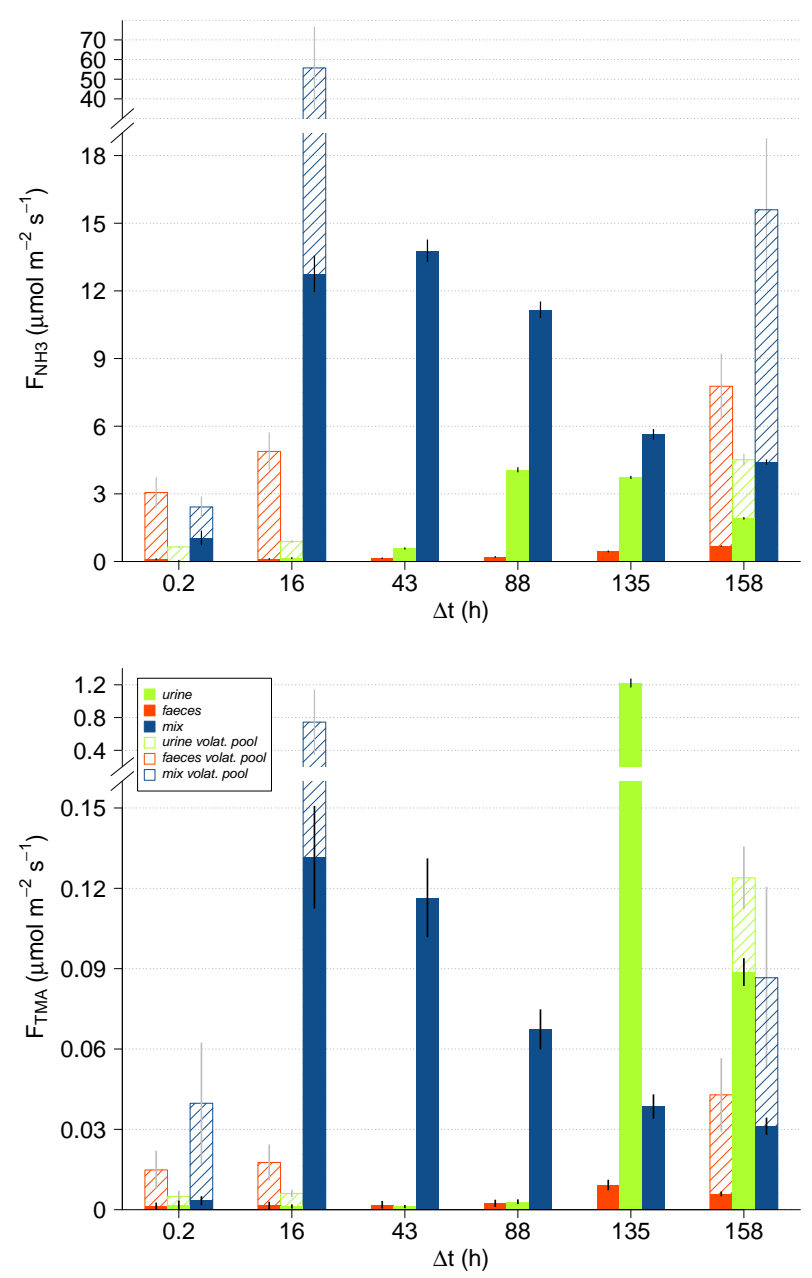

Figure 4. Dynamic chamber $\mathrm{NH}_{3}$ and TMA emission rates from samples of urine, faeces, and their mixture, as well as emission rates from parallel samples with $\mathrm{pH}$ raised $>12$ ("volatile emission pool").

to increase with increasing emissions. Specifically, faeces $\mathrm{pH}$ remained below 7 with a slight increase towards the end of the measurement period, mixture $\mathrm{pH}$ increased from 7.7 to 8.5 and declined down to 8.1 after $160 \mathrm{~h}$, and urine $\mathrm{pH}$ rose from 8.5 to 9.5 . Potential $\mathrm{NH}_{3}$ emissions were in general much larger than actual emissions, whereby the mixture exhibited the by far largest emission potential. $\mathrm{NH}_{3}$ emissions from stored slurry $\left(0.3 \mu \mathrm{mol} \mathrm{m} \mathrm{m}^{-2} \mathrm{~s}^{-1}\right)$ were lower than from the substrates because the composition of stored slurry reflects a long-term equilibrium.

TMA emissions behaved similarly to $\mathrm{NH}_{3}$ emissions. Only the urine-faeces mixture showed larger emissions continuing after the first $120 \mathrm{~h}$. The maximum flux during this period was $0.13 \mu \mathrm{mol} \mathrm{m}^{-2} \mathrm{~s}^{-1}$, and potential emissions were even higher. The following decrease down to $31.2 \mathrm{nmol} \mathrm{m}^{-2} \mathrm{~s}^{-1}$ remained far above the very small actual and potential TMA emissions from the stored slurry $(0.73$ and $1.3 \mathrm{nmol} \mathrm{m}^{-2} \mathrm{~s}^{-1}$ with 0.2 and $0.05 \%$ emission ratio, re- spectively). With the mixture, the TMA : $\mathrm{NH}_{3}$ emission ratio was of the order of $1 \%(0.3,1.0,0.9,0.6,0.7,0.7 \%$ for the periods in Fig. 4), consistent with the observations in Fig. 2. Faecal TMA emissions were continuously lowest, not exceeding $9.2 \mathrm{nmol} \mathrm{m}^{-2} \mathrm{~s}^{-1}$. Due to the acidic $\mathrm{pH}$, no significant emissions occurred, but also the emission potential of the volatile TMA pool was low. Until around $80 \mathrm{~h}$, urinary TMA emissions remained low with only minor emission potential during the first $24 \mathrm{~h}$. After $130 \mathrm{~h}$, however, a very large TMA emission peak, up to $1.2 \mu \mathrm{mol} \mathrm{m}^{-2} \mathrm{~s}^{-1}$, was observed, which decreased again towards the following measurement interval. We think this peak was induced by the contamination of the urine sample with some faecal residues on the $\mathrm{pH}$ electrode sometime after $88 \mathrm{~h}$. During storage, corresponding bacterial action was likely to have effectively converted the concentrated TMA precursor to TMA (see discussion Sect. 4.2). Considering that ambient temperatures are usually lower than the $20^{\circ} \mathrm{C}$ during our experiment (hence, more TMA will remain in the liquid phase) and assuming that in a real situation with a high stocking density there is a constant supply of excrements which mix and show an emission behaviour like the mixture in Fig. 4, we derive a typical average TMA emission rate of $10 \mathrm{nmol} \mathrm{m}^{-2} \mathrm{~s}^{-1}$ that we regard as representative for ambient situations.

\section{Discussion}

\subsection{TMA in exhaled air}

Kuhn et al. (2011) hypothesised oral TMA volatilisation from ruminating cattle as the main pathway for the generally enhanced TMA concentrations and emissions from agriculture. This might be due to TMA-enriched rumen content $(\mathrm{pH}=6.5)$ being mixed with saliva of high $\mathrm{pH}(\mathrm{pH}=8)$. In our measurements close to a ruminating cow's mouth, air influenced by the animal's respiration was characterised by short-term concentration peaks of acetone and $\mathrm{CH}_{4}$ (Fig. 1). Acetone, present in the blood, mainly originates from exhalation where it occurs on the ppm level (Dobbelaar et al., 1996; Elliott-Martin et al., 1997; Spinhirne et al., 2003; Turner et al., 2012). $\mathrm{CH}_{4}$ is created in the rumen as a by-product of enteric fermentation (Russell and Wallace, 1997) and is released during eructation and exhalation (Martin et al., 2012). $\mathrm{CH}_{4}$ release from the rumen dominates compared to release via the lung (http://c-lockinc.com/data.php). Elevated concentrations of $\mathrm{CH}_{4}$ and acetone are thus directly linked to the animal's respiration as can also be seen in Figs. 2 and 3. The high $\mathrm{CH}_{4}$ peaks appear less frequent than those of acetone, because $\mathrm{CH}_{4}$ is more related to eructation while acetone is rather associated with exhalation. Both time series are hence not well correlated. In order to support the hypothesis by Kuhn et al. (2011), strongly increased TMA : $\mathrm{NH}_{3}$ values should be observed when measuring close to a ruminating cow's mouth and when cattle stay in the barn yard. 
This was not evident from our measurements (Fig. 1). In fact, TMA concentration levels and TMA : $\mathrm{NH}_{3}$ ratios began to rise most strikingly only subsequent to the animals' presence in the yard (Fig. 2), which suggests that the main source for agricultural TMA volatilisation and high TMA : $\mathrm{NH}_{3}$ ratios cannot be oral release from ruminating cows. The amount of volatilised TMA during rumination is insufficient to yield the observed elevated TMA concentration episodes. This may be explained by limited gas exchange between mouth and atmosphere.

\subsection{Characteristics of TMA volatilisation}

Periods with highest TMA concentrations and TMA : $\mathrm{NH}_{3}$ ratios were found subsequent to the animals being in the barn yard and correlated with the existence of an excrement layer on the ground (Fig. 2). The TMA and $\mathrm{NH}_{3}$ concentrations in the afternoon exceeded those during morning. The higher temperatures promote the volatilisation of the alkaline constituents since solubility is decreased and the hydrolysis of urea is accelerated, leading to an increase of the $\mathrm{pH}-$ value. When the excrement layer was removed by a scraper and cleaned with water, the emissions and hence concentrations subsided. On one occasion (1 August) cleaning was omitted until the next morning resulting in persistently high TMA levels. Our dynamic chamber emission measurements (Fig. 4) demonstrate how TMA is most rapidly and efficiently released from a mixture of urine and faeces whereas urine and faeces alone exhibited rather small emission rates. Elevating the substrate's $\mathrm{pH}$ to $>12$ ("volatile emission pool") showed that very little TMA for volatilisation was available in urine and faeces alone. Hence, there is most likely a TMA precursor which is converted efficiently by the mixing of urine and faeces. The sudden massive TMA emission peak from urine after $135 \mathrm{~h}$ suggests that this precursor is contained within the urine. Several publications (see Sect. 4.3) show that TMA-N-oxide (TMAO) is excreted in urine by different mammals. We analysed urine from two Australian lactating cows for TMA and TMAO content using an established method (Johnson, 2008). Results reveal two to four times more TMAO than TMA (762$1121 \mu \mathrm{mol} \mathrm{TMAOL} \mathrm{L}^{-1}$ vs. $251-386 \mu \mathrm{mol} \mathrm{TMA} \mathrm{L}^{-1}$ ). This fraction likely varies from animal to animal depending on diet, health, and lactation status. Humans, as another example, excrete much more TMAO than TMA with urine (TMA : TMAO < 4\%; Lee et al., 2010). TMAO was discovered at the beginning of the twentieth century in animal tissues (Suwa, 1909). It appears to have manifold physiological functions and is, for example, an important compound in marine organisms for cellular osmotic and pressure regulation (Samerotte et al., 2007) and protein stabilisation (Bennion and Daggett, 2004; Sarma and Paul, 2013). The decomposition to TMA is responsible for the smell of decaying fish (Barrett and Kwan, 1985). The ratio of TMA : TMAO in hu-

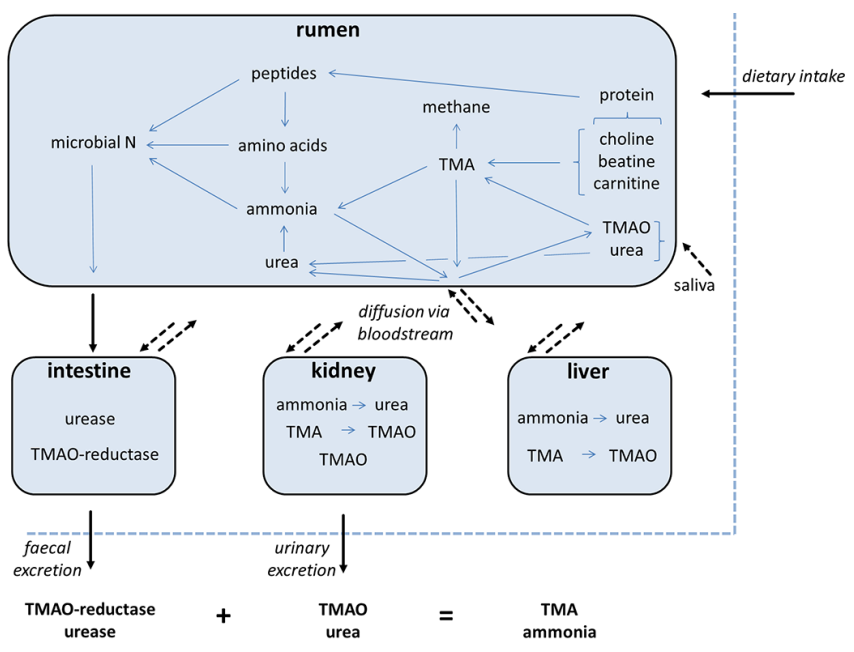

Figure 5. Main pathways of TMA and $\mathrm{NH}_{3}$ production by the ruminant system (with the focus on TMA).

man urine is, for example, used as a diagnostic tool for a disturbed metabolism (Cashman et al., 2003; Lee et al., 2010).

TMAO converting microbes are mainly abundant in the faeces. We propose that the dynamic chamber urine sample was contaminated by bacteria from the faeces sometime after $88 \mathrm{~h}$, probably through an insufficiently cleaned $\mathrm{pH}$ rod. The urine emission peak occurs for TMA but not for $\mathrm{NH}_{3}$, which demonstrates that different microbial species might have been responsible for the TMA creation than those for $\mathrm{NH}_{3}$ formation by urea hydrolysis. Alkaline conditions are required to make TMA available for volatilisation. Urea hydrolysis to $\mathrm{NH}_{3}$ increases $\mathrm{pH}$ and provides the conditions for TMA release into the gas phase.

\subsection{The fate of TMA in ruminants}

To the best of our knowledge, a picture of ruminant TMA formation, cycling, and volatilisation, complementing the schemes given by Bain et al. (2005) and Rappert and Müller (2005), has not yet been compiled. We attempt this with Fig. 5, schematically demonstrating the fate of $\mathrm{NH}_{3}$ and TMA in ruminants. As already indicated by Schade and Crutzen (1995), the primary source for TMA is the rapid microbial degradation of choline (Davies, 1936; Eddy, 1953; Neill et al., 1978; Zeisel et al., 1989; Bain et al., 2005; Wang et al., 2011; Craciun and Balskus, 2012) taken up with the feed (Pinotti et al., 2002). In addition, rumen microorganisms might metabolise TMA from dietary supply of carnitine, betaine, and TMAO (Davies, 1936; Mitchell et al., 1979; Zhang et al., 1999). The TMA is further used for methanogenesis. This removal process becomes saturated (Neill et al., 1978; Patterson and Hespell, 1979; Barrett and Kwan, 1985; Pinotti et al., 2002; Padmanabha et al., 2013). Rumen TMA has been found to accumulate with a molar ratio of dissolved TMA : $\mathrm{NH}_{3}$ of $1: 1.7$ to $1: 3.1$ (Kuhn et al., 2011). 
Like $\mathrm{NH}_{3}$, TMA diffuses through the rumen wall into plasma and blood stream (Bain et al., 2005). In the liver, the $\mathrm{NH}_{3}$ is converted to urea as a detoxification mechanism (Meijer et al., 1990; Walt, 1993). Similarly, TMA acts detrimentally (Guest and Varma, 1992; Rappert and Müller, 2005) while liver cells are capable of enzymatically oxidising TMA to TMAO (Baker and Chaykin, 1962; Baker et al., 1963; Gut and Conney, 1993; Bennett et al., 2013). Saliva is known to contain urea, serving as additional $\mathrm{NH}_{3}$ source in the rumen when being recycled (Wallace et al., 1997). Likewise, it seems reasonable also that TMAO, dissolved in the saliva, is being returned to the rumen, where it would be reconverted to TMA and then recycled back again to TMAO.

Several studies have found that a large TMA fraction from ingested precursor substances is excreted in form of urinary TMAO with various mammals (Davies, 1936; Norris and Benoit, 1945; Al-Waiz et al., 1987; Dacosta et al., 1990; Zhang et al., 1999). Once excreted, microorganisms reduce TMAO to TMA, subsequently convert TMA to DMA, then MMA, and finally to $\mathrm{NH}_{3}$ under aerobic conditions (Barrett and Kwan, 1985; Kim et al., 2001; Rappert and Müller, 2005). Microorganisms are known to feed on TMAO anaerobically as well (Kim et al., 2001; Baraquet et al., 2006). This behaviour generally appears to be similar to urea hydrolysis, and both processes are responsible for the rapid occurrence of high $\mathrm{NH}_{3}$ and TMA volatilisation rates when urine and faeces come into contact with one another (Fig. 4). The combination of both substrates is relevant since most urea- and TMAO-converting microorganisms are present in the intestine. For example, E. coli is found in the intestine and also occurs in excreted faeces where it can survive for weeks (Fremaux et al., 2008; Callaway et al., 2009; Hanajima et al., 2011) and can process TMAO to TMA under aerobic as well as anaerobic conditions (Gon, 2000; Baraquet et al., 2006; Ansaldi et al., 2007). Furthermore, TMA degradation occurs as stored slurry exhibits only minor TMA concentrations and emission potential (Sect 3.2; Kuhn et al., 2011). This is consistent with the observation that a variety of microorganisms are capable of efficiently degrading methylamines, including TMA, in the presence and absence of oxygen (Colby and Zatman, 1973; Colby et al., 1979; Patterson and Hespell, 1979; Jang et al., 1999; Rappert and Müller, 2005; Ho et al., 2008; Ferguson et al., 2008; Chen et al., 2011; Yang et al., 2013).

\subsection{TMA emission measurements in the context of literature}

There are aliphatic amine emissions related to poultry, sheep, horses, pigs, and cattle (Schade and Crutzen, 1995; Schade and Ngwabie, 2005). Emission flux measurements of amines are rare. Denmead et al. (1974) identified the occurrence of amine emissions by application of a micrometeorological gradient technique over an alfalfa pasture grazed by 200 sheep. They found indications of varying contributions of amine emissions to the total gaseous reduced nitrogen flux.
In a pig production facility, Feilberg et al. (2010) determined TMA emissions by monitoring barn exhaust ventilation rate and air concentrations. They found a TMA flux of $41 \mathrm{mg} \mathrm{h}^{-1}$ corresponding to $6 \mathrm{nmol} \mathrm{s}^{-1}$ per pig (however, there was also a slurry pit in the barn). Laubach et al. (2013) performed micrometeorological mass balance flux measurements of $\mathrm{NH}_{3}$ near a cattle herd with a stocking density of 150 animals per hectare on grassland and found additional (unquantified) emission fractions of amines. Downwind of a cattle feedlot with 840 animals per hectare, Hutchinson et al. (1982) determined $\mathrm{NH}_{3}$ and amine emissions from vertical concentration gradient measurements. The largest measured TMA emission constituted about $14.5 \mathrm{nmol} \mathrm{m}^{-2} \mathrm{~s}^{-1}$. The authors do not provide further direct information on determined TMA fluxes. Based on the given information, their TMA : $\mathrm{NH}_{3}$ emission flux ratio was between 0.3 and $0.5 \%$. Assuming an average ratio of $0.4 \%$ and using the tabulated $\mathrm{NH}_{3}$ emission rates results in a mean ( \pm standard deviation) TMA emission of $10.9 \pm 5.3 \mathrm{nmol} \mathrm{m}^{-2} \mathrm{~s}^{-1}$. This value compares well with the $10 \mathrm{nmol} \mathrm{m}^{-2} \mathrm{~s}^{-1}$ derived from our dynamic chamber experiments. It can be expected that the feedlot's high stocking density resembles conditions similar to situations in animal housing rather than, for example, for grazing cattle. Excrements cover the surface with high chances of urine and faeces interactions while there is ongoing supply. Thus, the measurements by Hutchinson et al. (1982) represent a setting comparable to our barn environment and the dynamic chamber emission trial.

With micrometeorological field measurements (eddy covariance and gradient), Kuhn et al. (2011) demonstrated that stored cattle slurry applied to grassland and cropland had only minor TMA emissions of up to $0.3 \mathrm{nmol} \mathrm{m}^{-2} \mathrm{~s}^{-1}$ with maximum TMA : $\mathrm{NH}_{3}$ ratios of $0.1 \%$. Direct analysis of the slurry TMA and $\mathrm{NH}_{3}$ content confirmed the low TMA emissions. Twigg et al. (2011) determined TMA emissions following 6-month-old cattle slurry applied to grassland by scaling eddy covariance-derived $\mathrm{NH}_{3}$ emissions (Whitehead et al., 2008) with the observed ambient TMA : $\mathrm{NH}_{3}$ concentration ratio (TMA determined by PTR-MS using a theoretical calibration factor). This yielded TMA emission rates of up to $3.6 \mathrm{nmol} \mathrm{m}^{-2} \mathrm{~s}^{-1}$ and a $31 \mathrm{~h}$ average emission rate of $0.69 \mathrm{nmol} \mathrm{m}^{-2} \mathrm{~s}^{-1}$. The concentration ratio TMA : $\mathrm{NH}_{3}$ was on average $0.38 \%$, and a maximum emission rate ratio of $0.74 \%$ was derived. These values are higher than expected from the results of this study and those of Kuhn et al. (2011). Nevertheless, we suggest that there is sufficient experimental and theoretical (Sects. 3.2 and 4.3) support for our observed low TMA emissions from stored slurry.

Currently, there are roughly $1.4 \times 10^{9}$ cattle on earth (FAO, 2013). Assuming that a surface between 0.5 and $5 \mathrm{~m}^{2}$ associated with each animal constantly emits 10 to $30 \mathrm{nmol} \mathrm{m}^{-2} \mathrm{~s}^{-1}$ yields a global emission of $0.003-$ $0.093 \mathrm{Tg}$ TMA-N $\mathrm{yr}^{-1}$. The upper estimate is a similar order of magnitude as the assessment of cattle emissions by Schade and Crutzen (1995) (0.083-0.167 Tg TMA-N yr ${ }^{-1}$ ) 
refined by Kuhn et al. (2011) (0.035-0.053 Tg TMA-N yr ${ }^{-1}$ ). This upscaling, based on our individual flux measurement experiments, provides a case study. Yet, it concurs well with the broad knowledge about agricultural TMA volatilisation as discussed above. Flux measurements under a wide range of environmental conditions would be required for a more detailed assessment.

\subsection{Emissions of reduced $\mathrm{N}$-species from agriculture and their role in secondary aerosol particle formation}

Nucleation of a cluster of a few molecules is the initial step of secondary aerosol formation. Aliphatic amines and $\mathrm{NH}_{3}$ have been identified as the neutralising components of secondary aerosol formation, which is initiated by sulfuric acid (Kulmala et al., 2013). While there is a consensus that amines are important for nucleation (Andreae, 2013; Kulmala et al., 2013), the differences between various amines regarding particle formation are not known in detail (Paasonen et al., 2012). Hence, it is assumed that aliphatic amines behave similarly and, explicitly, that TMA and DMA have similar nucleation enhancement potentials. Based on the comparison of modelling results under varying atmospherically relevant conditions to experimental results from seven different measurement sites, Paasonen et al. (2012) suggest that TMA provides the rate-limiting step for atmospheric particle formation. The presence of aliphatic amines has been shown to enhance formation rates more than thousand-fold compared to the ternary $\mathrm{NH}_{3}$-sulfuric-acid-water system, already at very low mixing ratios (e.g. in the case of 5 ppt of DMA compared to $250 \mathrm{ppt}$ of $\mathrm{NH}_{3}$ ) (Almeida et al., 2013). The quantum chemical modelling and experiments conducted by Almeida et al. (2013) resemble pristine atmospheric conditions considering DMA. The enhancing effect of TMA on secondary particle formation has been found in other modelling studies (Murphy et al., 2007; Kurten et al., 2008; Paasonen et al., 2012). Measurements of aerosol number concentration upwind, within, and downwind a cattle farm have demonstrated a threefold increase in particle concentration indicating secondary particle formation (Lammel et al., 2004).

Nucleation rates are higher with an aliphatic amine than with $\mathrm{NH}_{3}$; therefore, if for example DMA was present, it would be expected to enhance the particle formation. To what extent this happens is dependent on sulfuric acid and amine concentrations. When the amine concentration exceeds that of sulfuric acid, the nucleation rates observed by Almeida et al. (2013) will occur. If the amine concentration is lower than that of sulfuric acid, it is likely that $\mathrm{NH}_{3}$ also neutralises the remaining sulfuric acid-water clusters, and that the formation rate will be between the one determined by $\mathrm{NH}_{3}$ (lower limit) and amine (upper limit). Typical sulfuric acid mixing ratios range between 0.005 and $5 \mathrm{ppt}$ (Eisele and Tanner, 1993; Petäjä et al., 2009; Almeida et al., 2013). Unlike sulfuric acid, which is formed by oxidation of sulfur dioxide in the atmosphere (Boy et al., 2005), amines are emitted directly from their sources (this study; Ge et al., 2011). While the sulfuric acid gets re-supplied continuously, the availability of gaseous amines for particle formation is further determined by their overall atmospheric residence time. It is influenced by dry deposition, oxidation by radicals (mainly the hydroxyl radical $(\mathrm{OH})$ (TMA lifetime due to $\mathrm{OH}: 4.6$ to $7.7 \mathrm{~h}$; Ge et al., 2011)), and condensation onto existing particles. The lifetime due to condensation is the reciprocal of the condensation sink, which is determined by the aerosol number size distribution. The TMA lifetime due to condensation onto aerosol particles was calculated according to the condensation sink method by Kulmala et al. (2012), using the diffusion coefficient of TMA. We derive a TMA lifetime due to condensation in the range of 30 to $1000 \mathrm{~s}: 30 \mathrm{~s}$ for the case of a number size distribution (aerosol load) as found in the plume of a German cattle farm (Schneider et al., 2008) and several minutes in cleaner environments such as in a boreal forest in Finland (Dal Maso et al., 2007). Hence, the removal of gas-phase TMA is dominated by the condensation sink. Cattle barns and feedlots are emission hot spots for $\mathrm{NH}_{3}$, TMA, and also aerosol particles. The particles originate from both primary emissions as well as secondary formation. Given a lifetime of $60 \mathrm{~s}$, estimated to reflect a typical condensation sink with respect to central European aerosol particle concentrations, TMA and other aliphatic amines cannot travel far in the gas phase. For example, a plume with $3 \mathrm{~m} \mathrm{~s}^{-1}$ wind speed would advance $1.5 \mathrm{~km}$ within $8.4 \mathrm{~min}$, while the condensation sink would reduce the initial $10 \mathrm{ppb}$ down to $1 \mathrm{ppt}$. In addition to the loss of particles, the TMA plume is diluted with cleaner air during dispersion. Assuming typical boundary layer conditions, dilution of that plume over 8.4 min would down-mix the concentration of a (conservative) gas by roughly $1: 100$ (calculated by backwardLagrangian stochastic-based dispersion modelling in Flesch et al. (2004)). In the case of TMA, concentrations would have fallen below values typical for sulfuric acid. Consequently, gas-phase TMA can determine aerosol particle formation relatively close to the source while further away, $\mathrm{NH}_{3}$ begins to dominate the formation.

At the Finnish boreal forest research site in Hyytiälä there is experimental evidence that particle formation events coincide with episodes of increased ambient aliphatic amine concentrations (Kieloaho et al., 2013). The prevailing ambient conditions and commonly observed low pre-existing particle concentrations at the forest site differ strongly from those of densely populated intensive agricultural regions in, for example, central Europe, surrounded by anthropogenic activities leading to higher aerosol loading. 


\section{Conclusions}

To advance the understanding of agricultural TMA emission sources and their strength, we carried out detailed trace gas concentration measurements at a cattle barn as well as in laboratory experiments assessing TMA and $\mathrm{NH}_{3}$ emissions from excretion substrates. TMA is not exhaled from rumination in significant amounts but is formed from excreted TMAO by microbial action. The TMAO originates from rumen TMA which is oxidised by the liver. TMAO is mainly present in urine while microbes, providing the enzymatic conversion, are primarily contained in faeces. Hence, under usual conditions, a urine-faeces mixture will yield high TMA emission rates which could explain observed elevated ambient TMA concentrations at agricultural facilities. For TMA volatilisation, a situation with alkaline $\mathrm{pH}$ values is required; this occurs with urine-faeces mixtures due to bacterial urea hydrolysis into $\mathrm{NH}_{3}$. The formed TMA seems to be further microbially degraded to $\mathrm{NH}_{3}$ resulting in comparably small TMA emissions from stored slurry. Derived average TMA emission rates from urine-faeces mixtures are of the order of $10 \mathrm{nmol} \mathrm{m}^{-2} \mathrm{~s}^{-1}$ which roughly agrees with current global agricultural TMA emissions assessed by scaling with $\mathrm{NH}_{3}$ emission inventories.

Once emitted, gas-phase TMA participates in nucleation with a high potential efficiency for secondary particle formation but also undergoes condensation onto existing aerosol particles. Depending on the prevailing particle number size distribution, the corresponding atmospheric lifetime is estimated to range from 30 to $1000 \mathrm{~s}$, with the first value being probable for agricultural areas. This confines the high particle formation potential of agricultural TMA to its source regions, with dwindling direct impact of agricultural emissions at increasing distance. Close to agricultural sources, there are relatively high $\mathrm{NH}_{3}$ concentrations in addition to abundant amines. In the vicinity of farms, amines will be the key neutralising component in the ternary sulfuric acid-water base nucleation and can enhance the formation of new aerosol particles by a factor of 1000 compared to aerosol formation with $\mathrm{NH}_{3}$ under otherwise equal conditions. As the air mass is transported further away from the source, the amines are depleted and $\mathrm{NH}_{3}$ must become the primary neutralising agent. For more direct evidence of agriculturally enhanced secondary aerosol particle formation by amines, simultaneous measurements of gas-phase amines, $\mathrm{NH}_{3}$, sulfuric acid, and particle number size distributions should be performed upwind and downwind animal farms.

The Supplement related to this article is available online at doi:10.5194/bg-11-5073-2014-supplement.
Acknowledgements. This work was supported by the SNF grant IZK0Z2 139375/1 "Cow originated Amines/Ammonia, Towards True Levels of Emissions (CATTLE)". For funding we are also thankful to the European Science Foundation (ESF) for the project entitled "Tall Tower and Surface Research Network for Verification of Climate Relevant Emissions of Human Origin" (travel grant 4314), and the Academy of Finland Center of Excellence program (project no. 1118615). We thank Markku Kulmala, Tuomo Nieminen, and Katrianne Lehtipalo for many useful discussions on the role of amines in aerosol formation. We thank James M. Thyer from Melbourne, Australia, to organise the measurements of urine TMA/TMAO We are also grateful to Lukas Eggenschwiler and his team at Posieux research station who fulfilled all of our research requests.

Edited by: X. Wang

\section{References}

Almeida, J., Schobesberger, S., Kürten, A., Ortega, I. K., Kupiainen-Määttä, O., Praplan, A. P., Adamov, A., Amorim, A., Bianchi, F., Breitenlechner, M., David, A., Dommen, J., Donahue, N. M., Downard, A., Dunne, E., Duplissy, J., Ehrhart, S., Flagan, R. C., Franchin, A., Guida, R., Hakala, J., Hansel, A., Heinritzi, M., Henschel, H., Jokinen, T., Junninen, H., Kajos, M., Kangasluoma, J., Keskinen, H., Kupc, A., Kurtén, T., Kvashin, A. N., Laaksonen, A., Lehtipalo, K., Leiminger, M., Leppä, J., Loukonen, V., Makhmutov, V., Mathot, S., McGrath, M. J., Nieminen, T., Olenius, T., Onnela, A., Petäjä, T., Riccobono, F., Riipinen, I., Rissanen, M., Rondo, L., Ruuskanen, T., Santos, F. D., Sarnela, N., Schallhart, S., Schnitzhofer, R., Seinfeld, J. H., Simon, M., Sipilä, M., Stozhkov, Y., Stratmann, F., Tomé, A., Tröstl, J., Tsagkogeorgas, G., Vaattovaara, P., Viisanen, Y., Virtanen, A., Vrtala, A., Wagner, P. E., Weingartner, E., Wex, H., Williamson, C., Wimmer, D., Ye, P., Yli-Juuti, T., Carslaw, K. S., Kulmala, M., Curtius, J., Baltensperger, U., Worsnop, D. R., Vehkamäki, H., and Kirkby, J.: Molecular understanding of sulphuric acid-amine particle nucleation in the atmosphere, Nature, 502, 359-363, doi:10.1038/nature12663, 2013.

Andreae, M. O.: The aerosol nucleation puzzle, Science, 339, 911912, 2013.

Ansaldi, M., Théraulaz, L., Baraquet, C., Panis, G., and Méjean, V.: Aerobic TMAO respiration in Escherichia coli, Mol. Microbiol., 66, 484-494, doi:10.1111/j.1365-2958.2007.05936.x, 2007.

Al-Waiz, M., Mitchell, S. C., Idle, J. R., and Smith, R. L.: The relative importance of $\mathrm{N}$-oxidation and $\mathrm{N}$-demethylation in the metabolism of trimethylamine in man, Toxicology, 43, 117-121, 1987.

Bain, M. A., Fornasini, G., and Evans, A. M.: Trimethylamine: metabolic, pharmacokinetic and safety aspects, Curr. Drug Metab., 227-240, 2005.

Baker, J. R. and Chaykin, S.: The biosynthesis of trimethylamineN-oxide, J. Biol. Chem., 237, 1309-1313, 1962.

Baker, J. R., Chaykin, S., and Struempler, A.: A comparative study of trimethylamine-N-oxide biosynthesis, Biochim. Biophys. Acta, 71, 58-64, 1963. 
Baraquet, C., Theraulaz, L., Guiral, M., Lafitte, D., Mejean, V., and Jourlin-Castelli, C.: TorT, a member of a new periplasmic binding protein family, triggers induction of the Tor respiratory system upon trimethylamine N-oxide electron-acceptor binding in Escherichia coli, J. Biol. Chem., 281, 38189-38199, doi:10.1074/jbc.M604321200, 2006.

Barrett, E. L. and Kwan, H. S.: Bacterial reduction of trimethylamine oxide, Annu. Rev. Microbiol., 39, 131-149, 1985.

Barsanti, K. C., McMurry, P. H., and Smith, J. N.: The potential contribution of organic salts to new particle growth, Atmos. Chem. Phys., 9, 2949-2957, doi:10.5194/acp-9-2949-2009, 2009.

Bennett, B. J., Vallim, T. Q. D. A., Wang, Z., Shih, D. M., Meng, Y., Gregory, J., Allayee, H., Lee, R., Graham, M., Crooke, R., Edwards, P. A., Hazen, S. L., and Lusis, A. J.: Trimethylamine$\mathrm{N}$-oxide, a metabolite associated with atherosclerosis, exhibits complex genetic and dietary regulation, Cell Metab., 17, 49-60, doi:10.1016/j.cmet.2012.12.011, 2013.

Bennion, B. J. and Daggett, V.: Counteraction of urea-induced protein denaturation by trimethylamine N-oxide: a chemical chaperone at atomic resolution, P. Natl. Acad. Sci. USA, 101, 64336438, doi:10.1073/pnas.0308633101, 2004.

Blanes-Vidal, V., Hansen, M., Adamsen, A., Feilberg, A., Petersen, S., and Jensen, B.: Characterization of odor released during handling of swine slurry: Part I. Relationship between odorants and perceived odor concentrations, Atmos. Environ., 43, 2997-3005, doi:10.1016/j.atmosenv.2008.10.016, 2009.

Boy, M., Kulmala, M., Ruuskanen, T. M., Pihlatie, M., Reissell, A., Aalto, P. P., Keronen, P., Dal Maso, M., Hellen, H., Hakola, H., Jansson, R., Hanke, M., and Arnold, F.: Sulphuric acid closure and contribution to nucleation mode particle growth, Atmos. Chem. Phys., 5, 863-878, doi:10.5194/acp-5-863-2005, 2005.

Callaway, T. R., Carr, M. A., Edrington, T. S., Anderson, R. C., and Nisbet, D. J.: Diet, Escherichia coli O157: H7, and cattle: a review after 10 years, Curr. Issues Mol. Biol., 11, 67-79, 2009.

Cashman, J., Camp, K., Fakharzadeh, S., Fennessey, P., Hines, R., Mamer, O., Mitchell, S., Preti, G., Schlenk, D., Smith, R., Tjoa, S., Williams, D., and Yannicelli, S.: Biochemical and clinical aspects of the human flavin-containing monooxygenase form 3 (FMO3) related to trimethylaminuria, Curr. Drug Metab., 4, 151-170, doi:10.2174/1389200033489505, 2003.

Chen, Y., Patel, N. A., Crombie, A., Scrivens, J. H., and Murrell, J. C.: Bacterial flavin-containing monooxygenase is trimethylamine monooxygenase, P. Natl. Acad. Sci. USA, 108, 17791-17796, doi:10.1073/pnas.1112928108, 2011.

Colby, J. and Zatman, L. J.: Trimethylamine metabolism in obligate and facultative methylotrophs, Biochem. J., 132, 101-112, 1973.

Colby, J., Dalton, H., and Whittenbury, R.: Biological and biochemical aspects of microbial-growth on C1 compounds, Annu. Rev. Microbiol., 33, 481-517, doi:10.1146/annurev.mi.33.100179.002405, 1979

Craciun, S. and Balskus, E. P.: Microbial conversion of choline to trimethylamine requires a glycyl radical enzyme, P. Natl. Acad. Sci. USA, 109, 21307-21312, doi:10.1073/pnas.1215689109, 2012.

Dacosta, K., Vrbanac, J., and Zeisel, S.: The measurement of dimethylamine, trimethylamine, and trimethylamine $\mathrm{N}$-oxide using capillary gas-chromatography mass-spectrometry, Anal. Biochem., 187, 234-239, doi:10.1016/0003-2697(90)90449-J, 1990.
Dal Maso, M., Sogacheva, L., Aalto, P. P., Riipinen, I., Komppula, M., Tunved, P., Korhonen, L., Suur-Uski, V., Hirsikko, A., Kurtén, T., Kerminen, V.-M., Lihavainen, H., Viisanen, Y., Hansson, H.-C., and Kulmala, M.: Aerosol size distribution measurements at four Nordic field stations: identification, analysis and trajectory analysis of new particle formation bursts, Tellus B, 59, 350-361, doi:10.1111/j.1600-0889.2007.00267.x, 2007.

Davies, W. L.: 124. The metabolism of betaine and allied tertiary nitrogenous bases in the ruminant, J. Dairy Res., 7, 14-24, 1936.

Dawson, M. L., Perraud, V., Gomez, A., Arquero, K. D., Ezell, M. J., and Finlayson-Pitts, B. J.: Measurement of gasphase ammonia and amines in air by collection onto an ion exchange resin and analysis by ion chromatography, Atmos. Meas. Tech. Discuss., 7, 1573-1602, doi:10.5194/amtd-7-1573-2014, 2014.

Denmead, O. T., Simpson, J. R., and Freney, J. R.: Ammonia flux into atmosphere from a grazed pasture, Science, 185, 609-610, 1974.

Dobbelaar, P., Mottram, T., Nyabadza, C., Hobbs, P., ElliottMartin, R., and Schukken, Y.: Detection of ketosis in dairy cows by analysis of exhaled breath, Vet. Quart., 18, 151-152, doi:10.1080/01652176.1996.9694638, 1996.

Eddy, B.: Bacterial degradation of choline, Nature, 171, 573-574, doi:10.1038/171573b0, 1953.

Eisele, F. L. and Tanner, D. J.: Measurement of the gas phase concentration of $\mathrm{H}_{2} \mathrm{SO}_{4}$ and methane sulfonic acid and estimates of $\mathrm{H}_{2} \mathrm{SO}_{4}$ production and loss in the atmosphere, J. Geophys. Res., 98, 9001, doi:10.1029/93JD00031, 1993.

Elliott-Martin, R. J., Mottram, T. T., Gardner, J. W., Hobbs, P. J., and Bartlett, P. N.: Preliminary investigation of breath sampling as a monitor of health in dairy cattle, J. Agr. Eng. Res., 67, 267275, 1997.

FAO: FAO Statistical Yearbook 2012 - Europe and Central Asia, Food and Agriculture, Rome, Italy, 2013.

Feilberg, A., Liu, D., Adamsen, A. P. S., Hansen, M. J., and Jonassen, K. E. N.: Odorant emissions from intensive pig production measured by online proton-transfer-reaction mass spectrometry, Environ. Sci. Technol., 44, 5894-5900, doi:10.1021/es100483s, 2010.

Ferguson, T., Soares, J. A., Lienard, T., Gottschalk, G., and Krzycki, J. A.: RamA, a protein required for reductive activation of corrinoid-dependent methylamine methyltransferase reactions in methanogenic archaea, J. Biol. Chem., 284, 2285-2295, doi:10.1074/jbc.M807392200, 2008.

Filipy, J., Rumburg, B., Mount, G., Westberg, H., and Lamb, B.: Identification and quantification of volatile organic compounds from a dairy, Atmos. Environ., 40, 1480-1494, doi:10.1016/j.atmosenv.2005.10.048, 2006.

Finlayson-Pitts, B. J. and Pitts, J. N.: Chemistry of the Upper and Lower Atmosphere Theory, Experiments, and Applications, Academic Press, San Diego, available at: http://site.ebrary.com/id/ 10206472, 2000.

Flesch, T. K., Wilson, J. D., Harper, L. A., Crenna, B. P., and Sharpe, R. R.: Deducing ground-to-air emissions from observed trace gas concentrations: A field trial. J. Appl. Meteorol., 3, 487502, 2004.

Fremaux, B., Prigent-Combaret, C., and Vernozy-Rozand, C.: Long-term survival of Shiga toxin-producing Escherichia coli in 
cattle effluents and environment: an updated review, Vet. Microbiol., 132, 1-18, doi:10.1016/j.vetmic.2008.05.015, 2008.

Ge, X., Wexler, A. S., and Clegg, S. L.: Atmospheric amines - Part I. A review, Atmos. Environ., 45, 524-546, doi:10.1016/j.atmosenv.2010.10.012, 2011.

Gon, S.: Electron transfer and binding of the c-type cytochrome TorC to the trimethylamine $\mathrm{N}$-oxide reductase in Escherichia coli, J. Biol. Chem., 276, 11545-11551, doi:10.1074/jbc.M008875200, 2000.

Graus, M., Müller, M., and Hansel, A.: High resolution PTRTOF: quantification and formula confirmation of $\{\mathrm{VOC}\}$ in real time, J. Am. Soc. Mass Spectr., 21, 1037-1044, doi:10.1016/j.jasms.2010.02.006, 2010.

Grönberg, L., Lövkvist, P., and Jönsson, J..: Determination of aliphatic amines in air by membrane enrichment directly coupled to a gas chromatograph, Chromatographia, 33, 77-82, doi:10.1007/BF02276856, 1992.

Guest, I. and Varma, D. R.: Teratogenic and macromolecular synthesis inhibitory effects of trimethylamine on mouse embryos in culture, J. Toxicol. Env. Health, 36, 27-41, doi:10.1080/15287399209531621, 1992.

Gut, I. and Conney, A. H.: Trimethylamine N-oxygenation and Ndemethylation in rat liver microsomes, Biochem. Pharmacol., 46, 239-244, 1993

Hanajima, D., Fukumoto, Y., Yasuda, T., Suzuki, K., Maeda, K., and Morioka, R.: Bacterial community dynamics in aerated cow manure slurry at different aeration intensities: bacterial dynamics in aerated cow slurry, J. Appl. Microbiol., 111, 1416-1425, doi:10.1111/j.1365-2672.2011.05151.x, 2011.

Ho, K.-L., Chung, Y.-C., Lin, Y.-H., and Tseng, C.-P.: Biofiltration of trimethylamine, dimethylamine, and methylamine by immobilized Paracoccus sp. CP2 and Arthrobacter sp. CP1, Chemosphere, 72, 250-256, doi:10.1016/j.chemosphere.2008.01.044, 2008.

Hutchinson, G. L., Mosier, A. R., and Andre, C. E.: Ammonia and amine emissions from a large cattle feedlot, J. Environ. Qual., 11, 288-293, 1982.

IPCC: Climate Change 2013: The Physical Science Basis, Contribution of Working Group I to the Fifth Assessment Report of the Intergovernmental Panel on Climate Change, Cambridge University Press, New York, available at: https://www.ipcc.ch/report/ar5/wg1/\#.UwOFgHmKjbI, 2013.

Jang, M.-H., Basran, J., Scrutton, N. S., and Hille, R.: The reaction of trimethylamine dehydrogenase with trimethylamine, J. Biol. Chem., 274, 13147-13154, 1999.

Johnson, D. W.: A flow injection electrospray ionization tandem mass spectrometric method for the simultaneous measurement of trimethylamine and trimethylamine $\mathrm{N}$-oxide in urine, J. Mass Spectrom., 43, 495-499, doi:10.1002/jms.1339, 2008.

Jordan, A., Haidacher, S., Hanel, G., Hartungen, E., Märk, L., Seehauser, H., Schottkowsky, R., Sulzer, P., and Märk, T. D.: A high resolution and high sensitivity proton-transfer-reaction time-offlight mass spectrometer (PTR-TOF-MS), Int. J. Mass Spectrom., 286, 122-128, doi:10.1016/j.ijms.2009.07.005, 2009.

Kallinger, G. and Niessner, R.: Laboratory investigation of annular denuders as sampling system for the determination of aliphatic primary and secondary amines in stack gas, Mikrochim. Acta, 130, 309-316, doi:10.1007/BF01242921, 1999.
Kieloaho, A.-J., Hellén, H., Hakola, H., Manninen, H. E., Nieminen, T., Kulmala, M., and Pihlatie, M.: Gas-phase alkylamines in a boreal Scots pine forest air, Atmos. Environ., 80, 369-377, doi:10.1016/j.atmosenv.2013.08.019, 2013.

Kim, S.-G., Bae, H.-S., and Lee, S.-T.: A novel denitrifying bacterial isolate that degrades trimethylamine both aerobically and anaerobically via two different pathways, Arch. Microbiol., 176, 271-277, doi:10.1007/s002030100319, 2001.

Kuhn, U., Sintermann, J., Spirig, C., Jocher, M., Ammann, C., and Neftel, A.: Basic biogenic aerosol precursors: agricultural source attribution of volatile amines revised, Geophys. Res. Lett., 38, 1-7, doi:10.1029/2011GL047958, 2011.

Kulmala, M., Petäjä, T., Nieminen, T., Sipilä, M., Manninen, H. E., Lehtipalo, K., Dal Maso, M., Aalto, P. P., Junninen, H., Paasonen, P., Riipinen, I., Lehtinen, K. E. J., Laaksonen, A., and Kerminen, V.-M.: Measurement of the nucleation of atmospheric aerosol particles, Nat. Protoc., 7, 1651-1667, doi:10.1038/nprot.2012.091, 2012.

Kulmala, M., Kontkanen, J., Junninen, H., Lehtipalo, K., Manninen, H. E., Nieminen, T., Petaja, T., Sipila, M., Schobesberger, S., Rantala, P., Franchin, A., Jokinen, T., Jarvinen, E., Aijala, M., Kangasluoma, J., Hakala, J., Aalto, P. P., Paasonen, P., Mikkila, J., Vanhanen, J., Aalto, J., Hakola, H., Makkonen, U., Ruuskanen, T., Mauldin, R. L., Duplissy, J., Vehkamaki, H., Back, J., Kortelainen, A., Riipinen, I., Kurten, T., Johnston, M. V., Smith, J. N., Ehn, M., Mentel, T. F., Lehtinen, K. E. J., Laaksonen, A., Kerminen, V.-M., and Worsnop, D. R.: Direct observations of atmospheric aerosol nucleation, Science, 339, 943-946, doi:10.1126/science.1227385, 2013.

Kurtén, T., Loukonen, V., Vehkamäki, H., and Kulmala, M.: Amines are likely to enhance neutral and ion-induced sulfuric acid-water nucleation in the atmosphere more effectively than ammonia, Atmos. Chem. Phys., 8, 4095-4103, doi:10.5194/acp-8-4095-2008, 2008.

Kuwata, K., Akiyama, E., Yamazaki, Y., Yamasaki, H., and Kuge, Y.: Trace determination of low molecular weight aliphatic amines in air by gas chromatograph, Anal. Chem., 55, 21992201, 1983.

Lammel, G., Schneider, F., Brüggemann, E., Gnauk, T., Röhrl, A., and Wieser, P.: Aerosols emitted from a livestock farm in Southern Germany, Water Air Soil Poll., 154, 313-330, doi:10.1023/B:WATE.0000022962.65942.4b, 2004.

Laubach, J., Taghizadeh-Toosi, A., Gibbs, S. J., Sherlock, R. R., Kelliher, F. M., and Grover, S. P. P.: Ammonia emissions from cattle urine and dung excreted on pasture, Biogeosciences, 10, 327-338, doi:10.5194/bg-10-327-2013, 2013.

Lee, S.-K., Kim, D.-H., Jin, C.-B., and Yoo, H.-H.: Determination of urinary trimethylamine and trimethylamine $\mathrm{N}$-oxide by liquid chromatography-tandem mass spectrometry using mixedmode stationary phases, B. Korean Chem. Soc., 31, 483-486, doi:10.5012/bkcs.2010.31.02.483, 2010.

Lohmann, U. and Feichter, J.: Global indirect aerosol effects: a review, Atmos. Chem. Phys., 5, 715-737, doi:10.5194/acp-5-7152005, 2005.

Loukonen, V., Kurtén, T., Ortega, I. K., Vehkamäki, H., Pádua, A. A. H., Sellegri, K., and Kulmala, M.: Enhancing effect of dimethylamine in sulfuric acid nucleation in the presence of 
water - a computational study, Atmos. Chem. Phys., 10, 49614974, doi:10.5194/acp-10-4961-2010, 2010.

Martin, C., Koolaard, J., Rochette, Y., Clark, H., Jouany, J. P., and Pinares-Patiño, C. S.: Effect of release rate of the $\mathrm{SF}_{6}$ tracer on methane emission estimates based on ruminal and breath gas samples, Animal, 6, 518-525, doi:10.1017/S175173111100156X, 2012.

Meijer, A. J., Lamers, W. H., and Chamuleau, R.: Nitrogen metabolism and ornithine cycle function, Physiol. Rev., 70, 701748, 1990.

Mitchell, A., Chappell, A., and Knox, K.: Metabolism of betaine in the ruminant, J. Anim. Sci., 49, 764-774, 1979.

Murphy, S. M., Sorooshian, A., Kroll, J. H., Ng, N. L., Chhabra, P., Tong, C., Surratt, J. D., Knipping, E., Flagan, R. C., and Seinfeld, J. H.: Secondary aerosol formation from atmospheric reactions of aliphatic amines, Atmos. Chem. Phys., 7, 2313-2337, doi:10.5194/acp-7-2313-2007, 2007.

Neill, A., Grime, D., and Dawson, R.: Conversion of choline methyl-groups through trimethylamine into methane in rumen, Biochem. J., 170, 529-535, 1978.

Ngwabie, N. M., Schade, G. W., Custer, T. G., Linke, S., and Hinz, T.: Abundances and flux estimates of volatile organic compounds from a dairy cowshed in Germany, J. Environ. Qual., 37, 565-573, doi:10.2134/jeq2006.0417, 2008.

Norris, E. and Benoit, G.: Studies on trimethylamine oxide .3. Trimethylamine oxide excretion by the rat, J. Biol. Chem., 158, 443-448, 1945.

Paasonen, P., Olenius, T., Kupiainen, O., Kurtén, T., Petäjä, T., Birmili, W., Hamed, A., Hu, M., Huey, L. G., Plass-Duelmer, C., Smith, J. N., Wiedensohler, A., Loukonen, V., McGrath, M. J., Ortega, I. K., Laaksonen, A., Vehkamäki, H., Kerminen, V.-M., and Kulmala, M.: On the formation of sulphuric acid - amine clusters in varying atmospheric conditions and its influence on atmospheric new particle formation, Atmos. Chem. Phys., 12, 9113-9133, doi:10.5194/acp-12-9113-2012, 2012.

Padmanabha, J., Liu, J., Kurekci, C., Denman, S. E., and McSweeney, C. S.: A methylotrophic methanogen isolate from the thermoplasmatales affiliated RCC clade may provide insight into the role of this group in the rumen, Adv. Anim. Biosci., 4, 259, doi:10.1017/S2040470013000095, 2013.

Pape, L., Ammann, C., Nyfeler-Brunner, A., Spirig, C., Hens, K., and Meixner, F. X.: An automated dynamic chamber system for surface exchange measurement of non-reactive and reactive trace gases of grassland ecosystems, Biogeosciences, 6, 405429, doi:10.5194/bg-6-405-2009, 2009.

Patterson, J. A. and Hespell, R. B.: Trimethylamine and methylamine as growth substrates for rumen bacteria and Methanosarcina barkeri, Curr. Microbiol., 3, 79-83, 1979.

Petäjä, T., Mauldin, III, R. L., Kosciuch, E., McGrath, J., Nieminen, T., Paasonen, P., Boy, M., Adamov, A., Kotiaho, T., and Kulmala, M.: Sulfuric acid and $\mathrm{OH}$ concentrations in a boreal forest site, Atmos. Chem. Phys., 9, 7435-7448, doi:10.5194/acp9-7435-2009, 2009.

Pinotti, L., Baldi, A., and Dell'Orto, V.: Comparative mammalian choline metabolism with emphasis on the high-yielding dairy cow, Nutr. Res. Rev., 15, 315-331, doi:10.1079/NRR200247, 2002.

Pope, C. A., Burnett, R. T., Thun, M. J., Calle, E. E., Krewski, D., Ito, K., and Thurston, G. D.: Lung cancer, cardiopulmonary mor- tality, and long-term exposure to fine particulate air pollution, JAMA-J. Am. Med. Assoc., 287, 1132-1141, 2002.

Rappert, S. and Müller, R.: Microbial degradation of selected odorous substances, Waste Manage., 25, 940-954, doi:10.1016/j.wasman.2005.07.015, 2005.

Russell, J. B. and Wallace, R. J.: Energy-yielding and energyconsuming reactions, in: The Rumen Microbial Ecosystem, Blackie Academic \& Professional, London, New York, 246-282, 1997.

Samerotte, A. L., Drazen, J. C., Brand, G. L., Seibel, B. A., and Yancey, P. H.: Correlation of trimethylamine oxide and habitat depth within and among species of teleost fish: an analysis of causation, Physiol. Biochem. Zool., 80, 197-208, doi:10.1086/510566, 2007.

Sarma, R. and Paul, S.: Exploring the molecular mechanism of trimethylamine-N-oxide's ability to counteract the protein denaturing effects of urea, J. Phys. Chem. B, 117, 5691-5704, doi:10.1021/jp401750v, 2013.

Schade, G. W. and Crutzen, P. J.: Emission of aliphatic amines from animal husbandry and their reactions - potential source of $\mathrm{N}_{2} \mathrm{O}$ and HCN, J. Atmos. Chem., 22, 319-346, 1995.

Schade, G. W. and Ngwabie, N. M.: Emissionsmessungen von Volatilen Organischen Komponenten (VOK) aus der Tierhaltung, Tech. Rep. BLE-Projektnummer 514-33.26/04HS006, Institut für Umweltphysik der Universität Bremen, Bremen, Germany, 2005.

Schneider, F., Mahmoud-Yasin, N., and Onyeneke-Edwards, H.: Application of wide range aerosol spectrometer to specify particulate emissions from animal husbandry from 5 nano meter to 20 micrometer, in: Agricultural and Biosystems Engineering for a Sustainable World, International Conference on Agricultural Engineering, Greece, 23-25 June, 2008.

Seinfeld, J. H. and Pandis, S. N.: Atmospheric Chemistry and Physics: from Air Pollution to Climate Change, 2nd edn., John Wiley \& Sons, Inc., Hoboken, New Jersey, 2006.

Sintermann, J., Spirig, C., Jordan, A., Kuhn, U., Ammann, C., and Neftel, A.: Eddy covariance flux measurements of ammonia by high temperature chemical ionisation mass spectrometry, Atmos. Meas. Tech., 4, 599-616, doi:10.5194/amt-4-599-2011, 2011.

Spinhirne, J. P., Koziel, J. A., and Chirase, N. K.: A device for noninvasive on-site sampling of cattle breath with solid-phase microextraction, Biosyst. Eng., 84, 239-246, doi:10.1016/S15375110(02)00240-4, 2003.

Suwa, A.: Research into the organ extraction of selachie. II Announcement muscle extracts from dogfish sharks from which trimethylaminooxyd is obtained, Arch. Gesamte Physiol., 129, 231-239, 1909.

Taipale, R., Ruuskanen, T. M., Rinne, J., Kajos, M. K., Hakola, H., Pohja, T., and Kulmala, M.: Technical Note: Quantitative longterm measurements of VOC concentrations by PTR-MS - measurement, calibration, and volume mixing ratio calculation methods, Atmos. Chem. Phys., 8, 6681-6698, doi:10.5194/acp-86681-2008, 2008.

Trabue, S., Scoggin, K., McConnell, L., Maghirang, R., Razote, E., and Hatfield, J.: Identifying and tracking key odorants from cattle feedlots, Atmos. Environ., 45, 4243-4251, doi:10.1016/j.atmosenv.2011.04.081, 2011.

Turner, C., Knobloch, H., Richards, J., Richards, P., Mottram, T. T., Marlin, D., and Chambers, M. A.: Development of a de- 
vice for sampling cattle breath, Biosyst. Eng., 112, 75-81, doi:10.1016/j.biosystemseng.2012.03.001, 2012.

Twigg, M. M., House, E., Thomas, R., Whitehead, J., Phillips, G. J., Famulari, D., Fowler, D., Gallagher, M. W., Cape, J. N., Sutton, M. A., and Nemitz, E.: Surface/atmosphere exchange and chemical interactions of reactive nitrogen compounds above a manured grassland, Agr. Forest Meteorol., 151, 1488-1503, doi:10.1016/j.agrformet.2011.06.005, 2011.

Wallace, R. J., Onodera, R., and Cotta, M. A.: Metabolism of nitrogen-containing compounds, in: The Rumen Microbial Ecosystem, Blackie Academic \& Professional, London, New York, 283-328, 1997.

Walt, v. d. J. G.: Nitrogen-metabolism of the ruminant liver, Aust. J. Agr. Res., 44, 381-403, 1993.

Wang, Z., Klipfell, E., Bennett, B. J., Koeth, R., Levison, B. S., DuGar, B., Feldstein, A. E., Britt, E. B., Fu, X., Chung, Y.-M., Wu, Y., Schauer, P., Smith, J. D., Allayee, H., Tang, W. H. W., DiDonato, J. A., Lusis, A. J., and Hazen, S. L.: Gut flora metabolism of phosphatidylcholine promotes cardiovascular disease, Nature, 472, 57-63, doi:10.1038/nature09922, 2011.
Whitehead, J. D., Twigg, M., Famulari, D., Nemitz, E., Sutton, M. A., Gallagher, M. W., and Fowler, D.: Evaluation of laser absorption spectroscopic techniques for eddy covariance flux measurements of ammonia, Environ. Sci. Technol., 42, 20412046, doi:10.1021/es071596u, 2008

Yang, C.-F., Wang, C.-C., and Tseng, C.-H.: Methylamine removal using mixed bacterial strains in a continuous stirred tank reactor (CSTR) system, Nt. Biodeter. Biodegr., 85, 583-586, doi:10.1016/j.ibiod.2013.03.031, 2013.

Zeisel, S., Dacosta, K., Youssef, M., and Hensey, S.: Conversion of dietary choline to trimethylamine and dimethylamine in rats dose-response relationship, J. Nutr., 119, 800-804, 1989.

Zhang, A. Q., Mitchell, S. C., and Smith, R. L.: Dietary precursors of trimethylamine in man: a pilot study, Food Chem. Toxicol., 37, 515-520, 1999. 